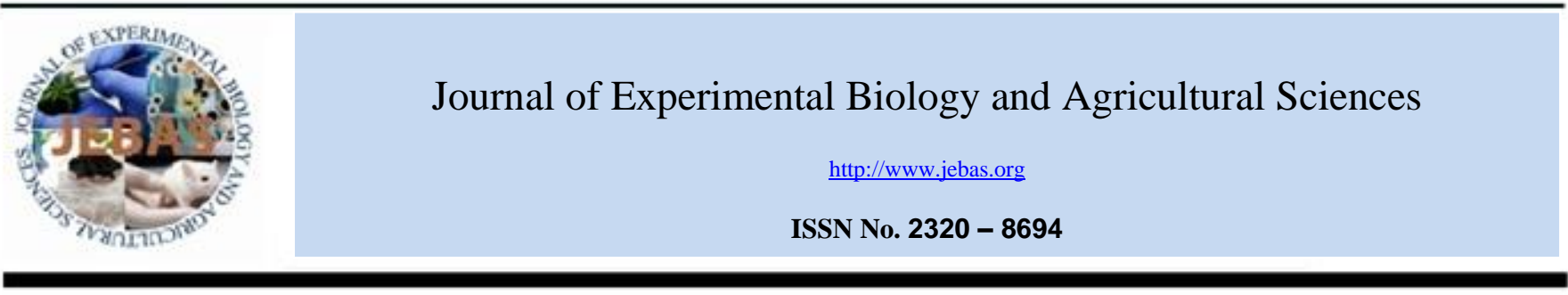

\title{
NANODIAGNOSTICS: A NEW FRONTIER FOR VETERINARY AND MEDICAL SCIENCES
}

\section{Upendra Lambe ${ }^{1}$, Minakshi $\mathrm{P}^{1, *}$, Basanti Brar $^{1}$, Madhusudan Guray $^{1}$, Ikbal $^{1}$, Koushlesh Ranjan ${ }^{2}$, Nitish Bansal ${ }^{1}$, Sandip Kumar Khurana ${ }^{3}$ and Manimegalai $\mathbf{J}^{1}$}

${ }^{1}$ Department of Animal Biotechnology, LUVAS, Hisar, Haryana, India

${ }^{2}$ Department of Veterinary Physiology and Biochemistry, SVPUAT, Meerut, U.P. India

${ }^{3} \mathrm{NRCE}$, Hisar, Haryana, India

Received - April 28, 2016; Revision - April 26, 2016; Accepted - May 21, 2016

Available Online - May 25, 2016

DOI: http://dx.doi.org/10.18006/2016.4(3S).307.320

KEYWORDS
Nanotechnology
Biosensors
Diagnostics
Veterinary
Medical

\begin{abstract}
Infectious diseases are one of the greatest threats to animal and human population living in the developing world. These diseases have capacity to instigate in a small area and then open out very fast to the rest of the world and causing a heavy pandemic situation, for example; avian influenza pandemic. Such diseases infect large masses of population and may lead to loss of lives and also incur huge economic losses. Therefore, the best way to control these diseases is by diagnosing it at a very primary level and taking necessary precautionary measures so as to avoid the spread. Since last few years, the diagnostic approach has changed from tedious molecular biological techniques, to easy and rapid diagnostic techniques. Nanotechnology has extended the molecular diagnostics limit to nanoscale. These developed techniques do not require sophisticated laboratories and expert personnel, and hence are a cheap diagnostic approach. These assays can also be performed at the field level where the patient is present and get the results there itself. Hence, they are also called as pen side test or lab on chip diagnostic assays. The biological tests using nanotechnology become quicker, more flexible and more sensitive. These techniques have greatly influenced the diagnostic approach in the veterinary as well as medical field. Especially in the developing countries such as India, where the laboratory services are not
\end{abstract}

* Corresponding author

E-mail: minakshi.abt@gmail.com (Minakshi P)

Peer review under responsibility of Journal of Experimental Biology and Agricultural Sciences.

Production and Hosting by Horizon Publisher India [HPI] (http://www.horizonpublisherindia.in/).

All rights reserved.
All the article published by Journal of Experimental Biology and Agricultural Sciences is licensed under a Creative Commons Attribution-NonCommercial 4.0 International License Based on a work at www.jebas.org.

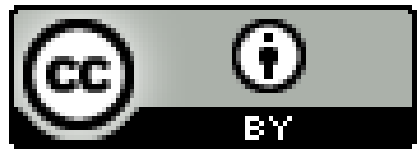


available at the village level, these techniques have facilitated the disease diagnosis the most. Nanotechnology also applies the tools and processes for nanofabrication which is used to build devices for studying biosystems. Molecular diagnostics incorporated with nanobiotechnology has improved clinical diagnosis and opened a new area for development of personalized medicine. Nanotechnology has also played a crucial role in designing of diagnostic assays for medical and veterinary use. The nano materials have many versatile optical properties, piezo-electric properties, thermal properties, electro-chemical properties, enzyme mimicking properties etc. By exploiting these properties, the workers have designed different approaches for diagnosis. In this review, different nano-diagnostic approaches for detection of pathogen have been stated.

\section{Introduction}

Bacteria, viruses and other microorganisms are omnipresent creatures which are responsible for causing disease in the humans and livestock. These organisms may affect multiple host species including humans. Therefore, they are of zoonotic importance and important in the public health concern. Some infectious agents can also be used as a part of biological warfare agent (MacKenzie, 2015). Hence, the correct diagnosis of the infectious agent gets primary importance, especially in case of livestock, because they are directly or indirectly linked to the humans through food webs. Several reasons can be attributed towards the diagnosis such as sub-clinical infections, persistently infected animals (PI), carrier or reservoir hosts, organisms transmitted through insect vectors or intermediate hosts (Rivera-Benitez et al., 2016; Navarro et al., 2016; Weber et al., 2016).

Therefore, if the infection can be detected at the very primary level before maximum population is affected, proper control measures can be planned and huge economic losses can be prevented (Cascio et al., 2011; Stephen et al., 2015). Biosensors are commonly used in medical and veterinary diagnostics because of their higher sensitivity, simplicity in operation, ability to perform multiplex analysis, etc. (Patel et al., 2016). Since last two decades tremendous research in the field of diagnostic science has resulted in the development of numerous tools for detection of pathological agents and various diseases they cause in the humans and the animals. These new techniques have so many advantages over the previous techniques (Wei \& Erkang, 2013). They are very handy, can be performed and interpreted by a layman, do not require sophisticated laboratories, very quick results with good specificity and sensitivity at a very cheap and affordable rate.

Besides, there is no need of transportation of samples to the labs, as the test can be performed at the point where the animal is standing, thus reducing sample upset (Baptista, 2014; Alharbi \& Al-Sheikh, 2014). Meanwhile, there is risk of spread on infectious disease, severe diseases conditions and even death due to absence of appropriate control measures (Dahlhausen, 2010). Apart from delayed diagnosis, other disadvantages such as possibilities of variations induced by transportation of samples, processing and testing conditions and even lack of uniform diagnostic platforms may further complicate the result and results generated may be doubtful. Now there are different strategies designed for the diagnosis of disease either by detection of $\mathrm{Ag}$ or $\mathrm{Ab}$, for which different types of biosensors are designed. In a Biosensor the physiological interaction between the ligand and the biorecognition element is converted by transducer, into measurable electric signal which can be further enhanced by a computer aided readout system for the user or sometimes can be read by naked eye only (Arora et al., 2010). Generally for the diagnosis of the disease, Ab based biosensors are preferred (Conroy et al., 2009). Mostly, the sensors are designed to diagnose the disease of veterinary importance as well as having zoonotic importance and vice versa (Stringer et al., 2008; Tran et al., 2012). Some have developed the sensors for surrogate human viruses so as to avoid the direct contact with the human viruses (Connelly et al., 2012). Therefore we need other techniques which can diagnose the disease at the point where the patient is present. Such techniques are the requirement for the developing countries like India.

Nanotechnology is an emerging field which has contributed the most for the development of the biosensor technological approach (Syed, 2014). A biosensor is a compact analytical device which employs a ligand-specific bio-recognition element, such as an antibody, enzyme, receptor, nucleic acid, aptamers, peptide/protein, cells, tissue or whole organisms. These elements are immobilized on a sensor surface which is integrated with a signal conversion unit or transducer (Ayyar \& Arora, 2013). Nanotechnology employs use of nanomaterials which exhibit physiochemical properties such as electrochemical (Rathee et al., 2016), chemical luminescence (Roda et al., 2016), optical (Tereshchenko et al., 2016), which are completely different than the actual material (Krejcova et al., 2015).

These properties are generally exploited in designing of biosensors. These days even smartphone integrated biosensors have developed (Diming \& Qingjun, 2016; Cevenini et al., 2016; Roda et al., 2016). There are many reports on nanoparticles having properties mimicking the properties of certain enzymes, thus these particles can be used in designing immunoassays. In this review, the Nano-diagnostic biosensors for the detection of pathogens which are human and veterinary importance are discussed. 


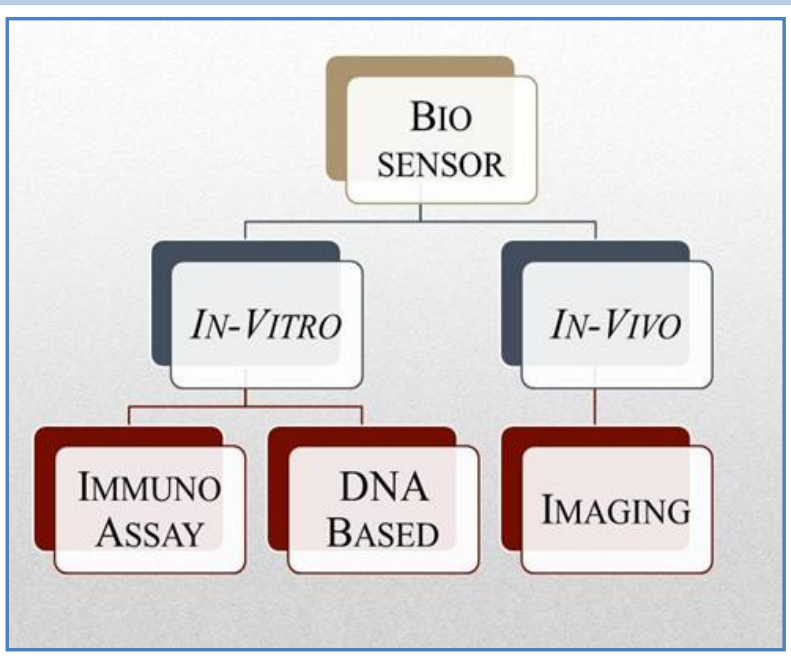

Figure 1 Types of Nano-diagnostic Biosensors

There are various approaches being used for the development of nano-diagnostic assays. The nano diagnostic can be classified into two categories, in-vitro and in-vivo. In-vivo is the diagnostic imaging techniques in case of live animals. On the other hand, the in-vitro techniques include, different antibody based immune assays and different nucleic acid based hybridization assays coupled to the nanoparticles (Figure 1). Several types of biosensor technologies have been used for detection of biomolecules.

\section{Immuno assays}

These are the label free assays which can detect the substrate without labeling the biomolecules with any enzyme. The Ag$\mathrm{Ab}$ reaction is detected by exploiting diverse properties of nanoparticles. Previously, immuno sensors exploited the very specific binding affinity of antibodies for a specific compound or antigen.

The binding of antigen to antibody follows the lock and key hypothesis of interaction. The antigen-antibody binding usually result in generation of a detectable signals from secondary molecules such as enzymes, fluorescent molecules or radioisotopes tagged with either antigen or antibody (Marazuela \& Moreno, 2002).

But due to advancements in nanotechnology, the need of labelling the biomolecule with enzyme or radioisotope is not required when Nano-particles are used (Tianshu et al., 2015). Several types of antibody/antigen interaction detection systems are available which are currently used for detecting diseases, (Table 1, Figure 2). IgG antibody based detection systems have been developed for diagnosis of autism (Gogolinska \& Nowak, 2013). For antigen/antibody based detection several types of silver and gold nanoparticles are used. Similarly, silver nanoparticles have been used for diagnosis of H1N1 virus (Yanxia et al., 2014) and gold nanoparticles have been used for diagnosis of Salmonella (Giyoung et al., 2015), Human T lymphotrophic virus and Hepatitis B Virus (Randolph et al., 2016) etc (Table 2).

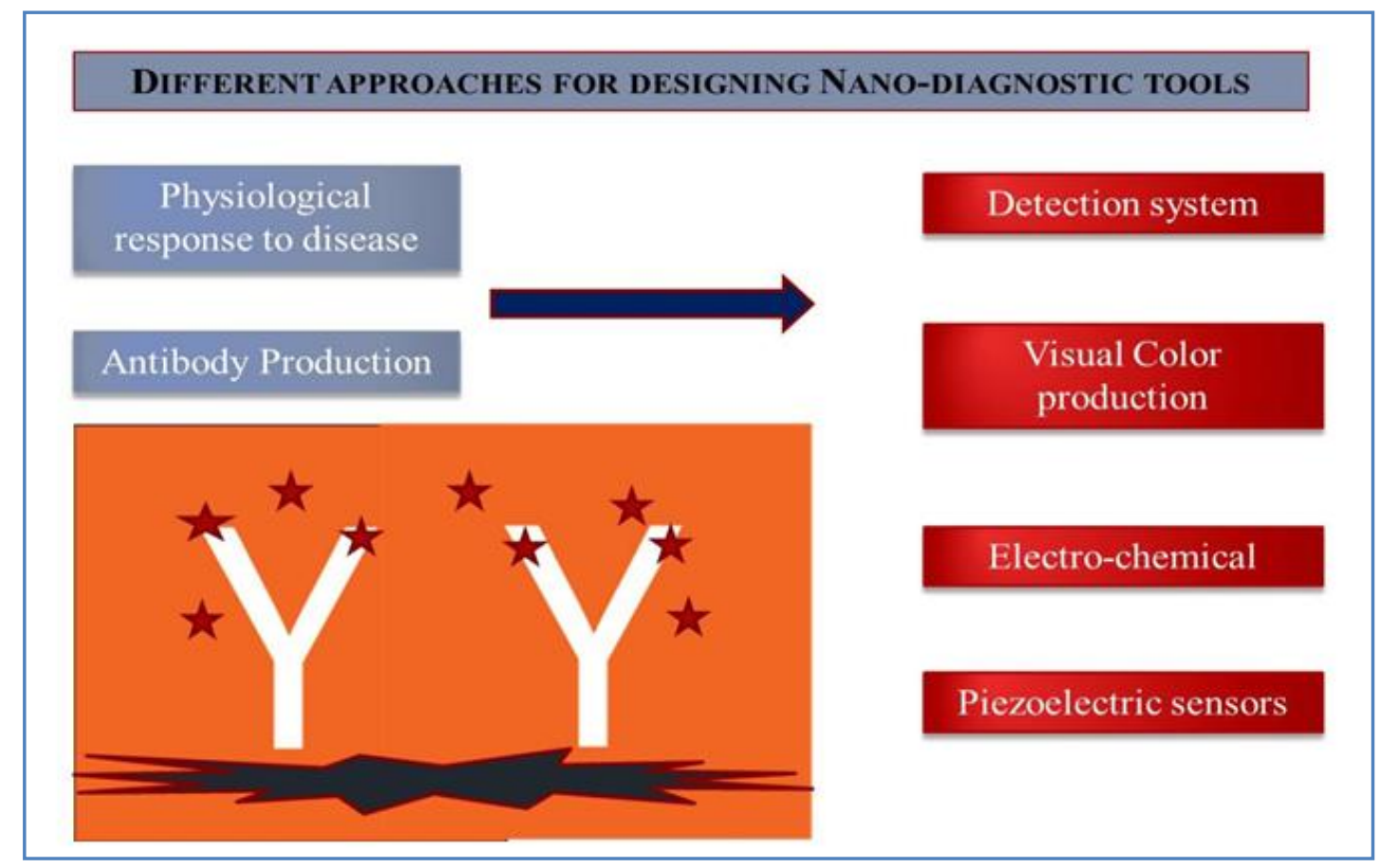

Figure 2 Different approaches for designing antigen/antibody based nano-diagnostic tools. 
Table 1 Lateral Flow assay for detection of various biological agents.

\begin{tabular}{|l|l|l|l|}
\hline Agent & Nanoparticle & Detection Limit & Reference \\
\hline HIV-1 & GNP & $0.24 \mathrm{pg} / \mathrm{ml}$ & Xiuli et al., 2016 \\
\hline HIV MYO & GNP & $1.56 \mathrm{ng} / \mathrm{ml}$ & Ruihua et al., 2016 \\
\hline Mycoplasma pneumonea & AF-647 & 0.3830 & Liming et al., 2016 \\
\hline TB & GNP & $100 \mathrm{pg} / \mathrm{ml}$ & Corstjens et al., 2016 \\
\hline Prostate specific Ag & Photon up-converting NPs & $41 \mathrm{ng} / \mathrm{liter}$ & Juntunen et al., 2016 \\
\hline Hepatitis C & GNPs & - & Hwan et al., 2015 \\
\hline Enterobacteriaceae & GNP & - & Jyoti et al., 2015 \\
\hline Mycotoxin & MNP & & Xie et al., 2015 \\
\hline
\end{tabular}

Table 2 Antigen/antibody interaction based system for detection of different pathogens.

\begin{tabular}{|l|l|l|l|l|}
\hline Organism & Nano Particle & Type of detection & Ag/Antibody & Reference \\
\hline Adeno virus & Triangular AuNPs & Raman Scattering & Polyclonal & Chia et al., 2011 \\
\hline H1N1 & Silver NPs & Fluorescence OPDA & Monoclonal & Yanxia et al., 2014 \\
\hline Encephalomyocarditis virus & Triangular AuNPs & Raman Scattering & Polyclonal & Chia et al., 2011 \\
\hline Salmonella & AuNPs & Microfluidic & Polyclonal & Giyoung et al., 2015 \\
\hline Duck Hepatitis virus & Silicon wafers & Ellipsometry Imaging & Polyclonal & Cheng et al., 2011 \\
\hline HIV & Fe-Au shell & Amperometric & Glycoprotein 160 & Ning et al., 2009 \\
\hline Salmonella pullorum & Blue Silica \& MNPs & Sandwich assay & Polyclonal & Qian et al., 2016 \\
\hline Salmenella & Quantum dots & Magnetic sensor & Polyclonal & Giyoung et al., 2015 \\
\hline Human T lymphotrophic virus & GNPs & Immunoaffinity assay & Monoclonal & Randolph et al., 2016 \\
\hline Hepatitis B Virus & GNPs & Immunoaffinity assay & Monoclonal & Randolph et al., 2016 \\
\hline Orchid Virus & Gold Nano rods & SPR & Label free & Lin et al., 2014 \\
\hline General Virus & GNP Chip & Fluorescence & Fluorescence Microscopy & Yen et al., 2016 \\
\hline H1N1, H5N1, H7N9 & ZnO Nano rods & PDMS & Electrochemical & Ji-Hoon et al.,2016 \\
\hline H1N1 & GNPs & Micro fluidic system & Aptamers & Tseng et al., 2016 \\
\hline
\end{tabular}

\subsection{Optical Biosensor}

The optical properties of nano-particles are exploited in an optical biosensor (Radhika et al., 2012). The Optical biosensors utilize several sensor techniques such as resonant mirrors, surface plasmon resonance and waveguides can be widely used for analysis of biomolecular interactions without using any molecular tag. Advances in instrumentation and experimental design have led to the increasing application of optical biosensors in many areas of diagnosis (Matthew, 2002). This means that when the conjugated nanoparticles bind to the specific molecules, they change their refractive index (Xudong et al., 2008) and therefore, change their color which is directly proportional to the number of interacting molecules or mass of the interacting molecules at that given instant. The techniques such as immune dot-blot assay, lateral flow assay work on the same principle. Several types of biosensors have been designed on optical detection principles (Figure 3), such as Surface plasmon resonance based biosensors; interferometer-based biosensors and optical waveguide based biosensors etc (Jeremy, 1997; Baird \& Myszka DG, 2001).

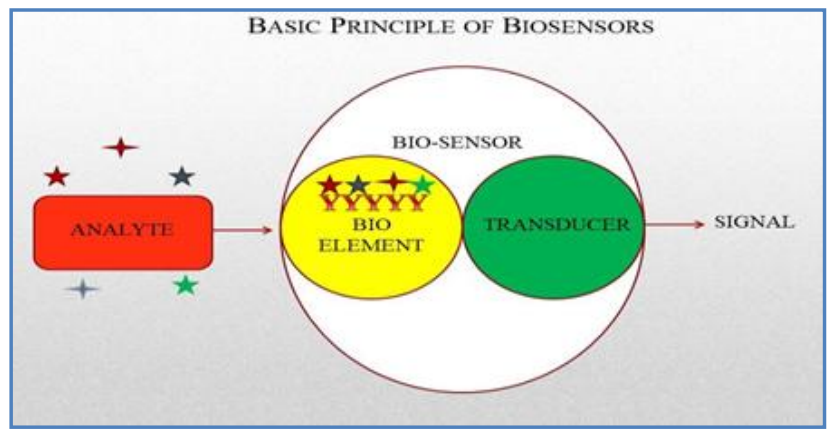

Figure 3 Basic principle of biosensors 


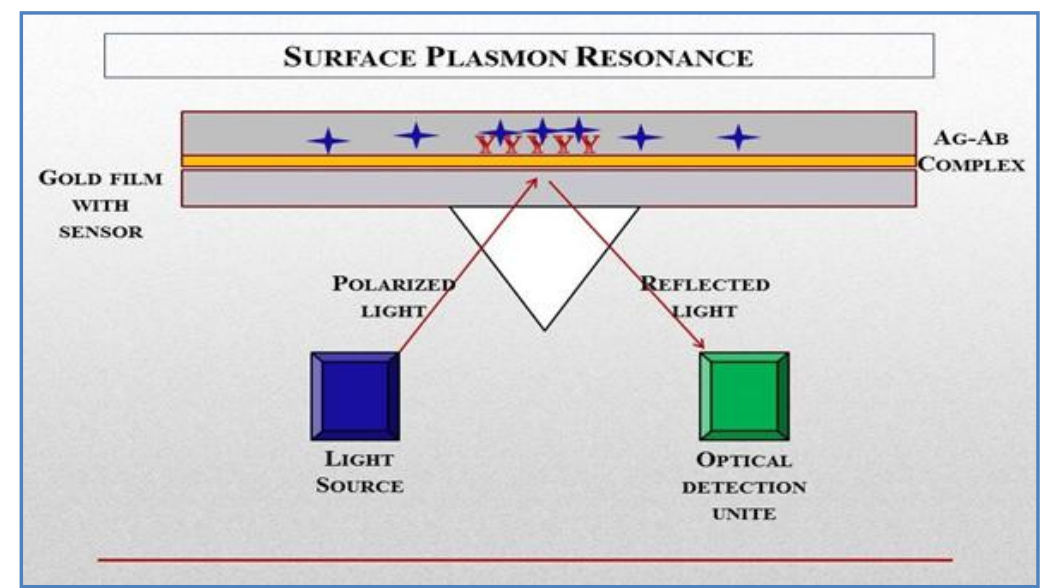

Figure 4 Surface plasmon resonance based principle.

\subsection{1: Surface plasmon resonance (SPR) biosensor}

It was first demonstrated for biosensing in 1983 by (Liedberg et al., 1983). Nanoparticles display unique physical properties due to their nano-size. Metallic nanoparticles have intense absorbance and scattering properties due to Surface Plasmon Resonance (SPR). When an oscillating electric field interacts with the free conductive band of electrons at the surface of the AuNP, collective dipolar oscillation of the electrons occurs. This is called Surface Plasmon (Radwan \& Azzazy, 2009). SPR has been extensively explored and has gradually become a very powerful label-free tool to detect the pathogens (Pattnaik, 2005; Homola, 2003). In SPR, a surface plasmon wave (SPW) which is a charge density oscillation occurs at the interface of two media with dielectric constants of opposite signs, such as a metal (gold or silver) and a dielectric (Figure 4).

This technique has been successfully used for the detection of viruses and bacteria (Boltovets et al., 2004). Gold nanoparticles embedded PVA matrix is used as sensing material (Rithesh et al., 2016). Detection can be performed by visual colour change observations, photometry or resonance light scattering by interacting molecules on surface of nanoparticles deciphered by changing refractive index. This has a very wide range of applications in the areas of environmental, pharmaceutical and biological analysis and clinical diagnosis (Yanlin et al., 2016). Gurpreet et al. (2016) has reported the use of this type of biosensors in the detection of Niesseria meningitides.

SPR sensors can visualize living cell interactions which can be used for malignant cell detection in cellular diagnostic systems (Yanase et al., 2014). SPR based rapid immunoglobulin M (IgM) diagnostic test has been successfully used for detection of dengue from human serum in only 10 minutes with $100 \%$ specificity and 83-93\% sensitivity (Jahanshahi et al., 2014). The SPR biosensor based assay was also used for simultaneous detection of multiple TB antibodies in patient serum with high sensitivity and specificity in real-time (Hsieh et al., 2012).

\subsubsection{Interferometer-based biosensors}

Optical interferometers have already used in detection of surface bound bio-reactants such as bacteria, spores, toxins, viruses, and proteins (Schneider et al., 2000; Schmitt et al., 2007). These devices are based on evanescent field sensing. Light is confined within the core of the waveguide, and extends into the surrounding media so that its field can interact with the environment. Therefore, a biomolecular interaction takes place between a receptor molecule, previously deposited on the waveguide surface, and its complementary analyte produces a change in the refractive index at the sensor surface that induces a variation in the optical properties of the guided light via the evanescent field. Interferometric assays have an advantage in detection of intact bacterial or viral particles. Influenza virus has been detected in oral-nasal secretion of patients at concentrations of a few $\mathrm{ng} / \mathrm{mL}$ through this technique. Recent study shows that microorganism growth can also be detected using hollow-core photonic fiber based FabryPerot interferometer (Xiaohui et al., 2016). A label-free DNA biosensor based on microfiber-assisted Mach-Zehnder interferometer for in-situ real-time DNA hybridization kinetics detection has been experimentally demonstrated by (Binbin et al., 2016). While Mach-Zehnder interferometer point-of-care system for rapid multiplexed detection of microRNAs in human urine specimens is done by (Qing et al., 2015). Sandwich assay for detection of Streptavidin was demonstrated by (Wenjie et al., 2016) with detection limit of $0.02 \mathrm{nM}$. The Interferometric biosensor was used for detection of Aflatoxin M1. The test result was highly reproducible and reusable (Chalyan et al., 2016). A fiber-optic interferometer based optic biosensor operating at $1550 \mathrm{~nm}$ was evaluated for quantification of gelatin (protein) in water (Yadav et al., 2014). 
Table 3 Enzymatic interactions based detection of different agents associated with health concern.

\begin{tabular}{|l|l|l|l|l|}
\hline Compound & Nanoparticle & Type of sensor & Detection molecule & References \\
\hline Norepinephrine & FeMoO4 rods & Cyclic voltammetry & Without modification & Kunda et al., 2016 \\
\hline IFN Gamma & AuNP & ITO & HPR-Ab & Yaru et al., 2016 \\
\hline Protein estimation & MNPs & Colorimetric & Punctates & Gero et al., 2016 \\
\hline IL-3 & AuNP & iPCR & Polyclonal Ab & Lucie et al., 2011 \\
\hline Stem cell factor SCF & GNP & iPCR & Polyclonal Ab & Lucie et al., 2011 \\
\hline Nano Mass & Graphene films & Ultrasound frequency shift & Piezoelectric crystal & Li \& Wang, 2016 \\
\hline
\end{tabular}

\subsubsection{Optical waveguide based biosensors}

Optical waveguides based biosensor utilize fluorescence resonance energy transfer (FRET) triggered by the binding event between multivalent protein and dye-tagged receptors (Song et al., 2000). It is successfully adapted to the detection of biomarkers for complex biological material. The spatial filtering of wave-based detection is a distinct advantage as it ensures that the bulk biological material is not irradiated. This arrangement effectively minimizes background fluorescence and eliminates the need for extensive sample preparation when analyzing complex samples. Mukundan et al. (2009) have successfully used this approach to detect extremely low concentrations of disease biomarkers in patient samples. Optical wave guide biosensors are used for the detection of RNA in the samples (Carrascosa et al., 2016).

\section{Enzymatic interactions based nanodiagnostics}

Enzymes are very popular bioreceptors due to their specific binding capabilities and catalytic activity. Enzymatic interaction is used for specific analyte recognition (Pohanka, 2013). The enzyme based biosensors provide specific advantages such as ability to catalyze several reactions, can detect many analytes such as substrates, products, modulators and inhibitors. Moreover, enzymes are not consumed in reactions. Therefore, biosensor can be used continuously without loss of activity. Enzymatic interactions methods can detect much lower limit of analytes (Patel et al., 2016). However, the sensor lifetime depends on enzymatic stability (Lucie et al., 2011).There are several types of enzymatic interactions detection systems are available which are currently used for detection of agent associated with health concern (Table 3).

Several biological molecules such as IL-3 (Lucie et al., 2011), IFN Gamma (Yaru et al., 2016), total protein (Gero et al., 2016) etc., in disease conditions have been estimated using enzymatic interaction based biosensor. Recently, there has been little advancement in these types of biosensors like, the accumulation of insulin causes type 2 diabetes. To detect this condition a biosensor called Nano-cage-mediated refolding of insulin by PEG-PE micelle has been developed (Xiaocui et al., 2016). Cholin a breast cancer marker, detected form serum by nano interface technology (Thiagarajan et al., 2016). Similarly, blood glucose level is monitored by a noninvasive saliva biosensor (Wenjun et al., 2015). Aptamer based GnRH biosensor in equine urine has been demonstrated by (Richards et al., 2016).

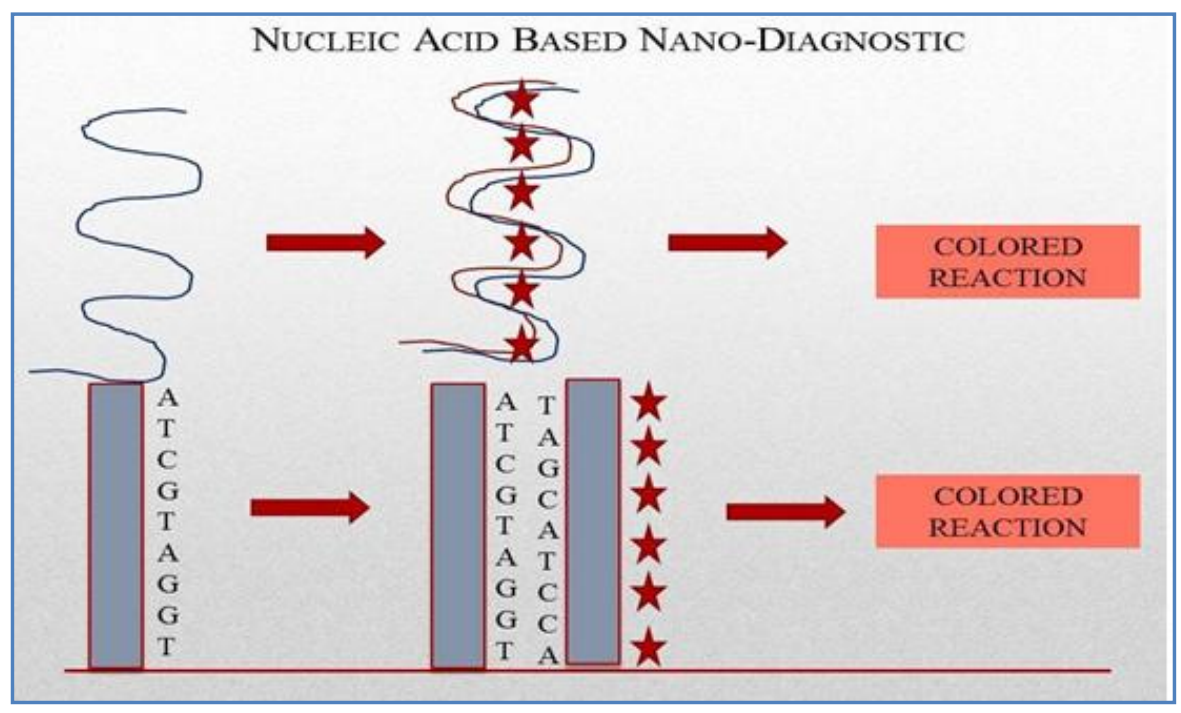

Figure 4 Approaches for making Nucleic acid based diagnostics 
Table 4 Nucleic acid interactions based nano-diagnosis detection of different agents associated with disease.

\begin{tabular}{|l|l|l|l|l|}
\hline Organism & Nanoparticle & Sensor type & Nucleic acid & Reference \\
\hline Arabis Mosaic Virus & SMP & Magnetic & RNA & Ning et al., 2014 \\
\hline Lily Symptomless Virus & SMP & Magnetic & RNA & Ning et al., 2014 \\
\hline HSV & SMP & Magnetic & RNA & Ning et al., 2014 \\
\hline GYSVD & SMP & Magnetic & RNA & Ning et al., 2014 \\
\hline HBV & AuNP & Barcode amplification & DNA oligos & Wang et al., 2010 \\
\hline HBV & MNPs & Hybridization & DNA oligo & Wang et al., 2010 \\
\hline Dengu & 3D Graphene & Impedimetric sensor & RNA & Seon et al., 2016 \\
\hline Canine adeno & GNPs & Microarray chip & DNA & Yadav et al., 2015 \\
\hline Salmonella & GNPs & LFICA & 16s rRAN & Cheng et al., 2013 \\
\hline HBV & Cu Nano cluster & Colorimetry & DNA & Xiaoxia et al., 2016 \\
\hline Influenza virus & CdZnTeS Quantum dots & Fluorescence & Molecular beacons & Oluwasesan et al., 2016 \\
\hline White spot syndrome virus & GNPs & LAMP & DNA oligo & Yortyot et al., 2013 \\
\hline Porcine epidemic diarrhea & GNPs & Nano RT-PCR & RNA & Wanzhe et al., 2015 \\
\hline Influenza & Sugar chain GNP & RT qPCR & SYBRgreen & Yasuo et al., 2015 \\
\hline HCV & GNPs & Hybridization & 5’UTR DNA & Sherif et al., 2010 \\
\hline
\end{tabular}

\section{Nucleic acid interactions based nanodiagnostics}

The nucleic acid based Biosensors are known as genosensors. The analyte recognition is based on principle of nucleotide base pair complementarity, such as A: T and C: G in DNA. Complementary (probe) sequences are synthesized from target nucleic acid sequence, labeled with suitable dye and immobilized on bio sensor chip. Thus, probe will hybridize with target gene followed by generation of optical signals (Marazuela and Moreno, 2002). There are several types of Nucleic acid (DNA/RNA) interaction detection systems available which are used for detection of several viruses or other disease associated agents (Table 4; Figure 4).

The DNA genosensors can be combined with PCR amplification for detection of several microorganisms. The DNA genosensors based assays lead to direct detection of hybridization process using electrochemical redox mediators, enzyme amplification or nanoparticles labeled ingredients (Pedrero et al., 2011). Nucleic acid based biosensors have also used for screening of allergens in food materials because of high stability of DNA in comparison to proteins even after processing of food (Mafra et al., 2008). The assay is based on selection of DNA target sequences coding allergenic proteins.

Such techniques are also used for animal meat identification. Bovine and sheep meat samples were detected by targeting highly repetitive satellites DNA ( 250 bp and 430 bp, respectively) (Mascini et al., 2005). A more reliable and faster genosensors based technique has been developed for chicken, bovine and swine meat identification. This method uses a combination of isothermal amplification of DNA along with electrochemical detection of DNA on disposable carbon based electrochemical printed chips (Ahmed et al., 2010). Genosensors are also used for monitoring of genetically modified organisms (GMO) having specific genes (transgene) introduced into their DNA using genetic engineering to improve crop production (by insect or herbicide resistance) or to enhance nutritional properties. Target gene selections for such genosensors are relatively easy because the transgenic inserts sequences are completely known and available in open databases. Several genosensors have been developed for detection of transgene from GMOs (Yang et al., 2007a; Yang et al., 2007b; Yang et al., 2008; Feng et al., 2008; Jiang et al., 2008; Ma et al., 2008; Zhang et al., 2008; Yang et al., 2009; Zhou et al., 2009; Bonanni et al., 2009; Jiang et al., 2011; Yang et al., 2012; Arugula et al., 2014; Manzanares-Palenzuela et al. 2015).

\section{DNA based nanotechnology}

DNA nanotechnology utilizes newly designed artificial nucleic acid structures for analytical purposes. In such assays, nucleic acids are used as non-biological engineering materials rather than as carrier of genetic information. Some researchers have designed static structures with DNA, such as DNA computers and molecular machines (Seeman \& Nadrian, 2004). There are different DNA based technology such as Microarray, Rolling circle amplification, Threshold mediated strand displacement (TMSD) and L shaped DNA probes in which nanoparticle were used to facilitate the process (Shi et al., 2014; Ravan, 2016; Elham et al., 2016) (Table 5). The nano-biotechnology system may be used for creation of a DNA robot which can recognize infected cells and induce apoptosis to kill such cells (Douglas et al., 2012). The DNA robot was an elegant model system which has shown great potential for uses as a smart drug. The DNA nanotechnology science has also been used as carriers for Doxorubicin (anticancer drug) (Jiang et al., 2012; Zhao et al., 2012). This showed increased potency of Doxorubicin as compared to normal medication. Thus, DNA nanotechnology has shown breathtaking pace in recent years. It leads to control of structure and function at molecular level with unparallel efficiency (Tørring \& Gothelf, 2013). 
Table 5 Nanoparticles facilitated nucleic acid based technologies.

\begin{tabular}{|l|l|l|l|l|}
\hline Technique & Nanoparticle & Sensor type & Nucleic acid & Reference \\
\hline Micro Array & GNPs & Pixel sensors & DNA & Wang et al., 2010 \\
\hline Rolling circle amplification & GNPs & SPR & DNA probes & Shi et al., 2014 \\
\hline Threshold mediated strand displacement & GNPs & TMSD & RNA & Ravan, 2016 \\
\hline L shaped DNA probes & GNPs & Hybridization & DNA & Elham et al., 2016 \\
\hline RNA quantification & GNPs & Colorimetry & PNA peptide nucleic acid & Joshi et al., 2013 \\
\hline
\end{tabular}

Nano-Immuno-PCR

Nano-Immuno-PCR has additional sensitivity than other conventional methods because it utilizes combined effect of nucleic acid amplification along with an antibody-based assay (Guangxin et al., 2015). It uses a DNA-antibody conjugate as a bridge which links the immunoreaction with PCR reaction. This method has better specificity and $10^{9}$ fold more sensitivity than conventional ELISA assay (Ruiyan \& Huisheng, 2015; Chang et al., 2016). The latest advancements in this technique include better production of DNA-antibody conjugate and better readout methods. It also has broad range of applications in clinical diagnostics because it is an ultrasensitive protein detection assay (Chang et al., 2016). Several developed NanoImmuno-PCR assays for disease diagnosis have been listed in the Table 6.

\section{Conclusion}

Nanomaterials offer a vast number of breakthroughs such as cost effective, lower risk to consumers and faster approach that will further enhance the clinical aspect of veterinary sciences in future and conceived that bacterial infections can be eliminated in the patient within minutes, instead of using treatment with antibiotics over a period of weeks. Nanotechnology has found its way into the food industry to improve food shelf life, safety and quality control. In coming years it can be expected that nanotechnology may practically apply in artificial creation of cells, tissues and organs. The artificial cells can be used in replacement of defective cells and organs, especially in metabolic disorders. Nanotechnologies have power to extent the modern molecular diagnostics to personalized medicine and therapeutics. Such techniques have been used in the field of pathogen detection, DNA detection assay, biomarker discovery and cancer diagnosis. Nano medicine also has important role in future therapeutics as well as diagnostic assays. Although nanotechnologies have several applications and benefits, it is still in the early stages of its development and yet to apply throughout the world for routine diagnostics and therapeutics approaches.

\section{Conflict of interest}

Authors would hereby like to declare that there is no conflict of interests that could possibly arise.

\section{References}

Ahmed MU, Hasan Q, MosharrafHossain M, Saito M, Tamiya E (2010) Meat species identification based on the loop mediated isothermal amplification and electrochemical DNA sensor. Food Control 21: 599-605. doi: 10.1016/j.foodcont.2009.09.001.

Alharbi KK, Al-Sheikh YA (2014) Role and implications of nanodiagnostics in the changing trends of clinical diagnosis. Saudi Journals of Biological Sciences 21:109-117. doi: 10.1016/j.sjbs.2013.11.001.

Arora S, Pastorella G, Byrne B, Marsili E, O'Kennedy R (2010) Microbial cells and biosensing: a dual approachexploiting antibodies and microbial cells as analytical/power systems. In: Zacharis CK, Tzanavaras PD (Eds.), Reviews in Pharmaceutical and Biomedical Analysis, Bentham Science Publishers Sharjah, UAE, 63-75.

Table 6 Nano-Immuno PCR for detection of biological analytes.

\begin{tabular}{|l|l|l|l|}
\hline Analyte & Nanoparticle & Detection limit & Reference \\
\hline Diethyle phthalate DEP & GNP & $4 \mathrm{pg} /$ liter & Ruiyan \& Huisheng 2015 \\
\hline Aroclor 1248 & GNP & $2.55 \mathrm{pg} / \mathrm{liter}$ & Guangxin et al., 2015 \\
\hline Tuberculosis Ag85B & GNP & $90.9 \%$ & Netrapal et al., 2016 \\
\hline Alzheimer's disease Tau marker & GNP & Superior to ELISA & Stegurova et al., 2014 \\
\hline Nasopharyngeal carcinoma NPC & MWCNT & $1: 10,000,000$ & Ching et al., 2016 \\
\hline Hantaan Virus Nucleucapside & GNP & $10 \mathrm{fg} / \mathrm{ml}$ & Longyan et al., 2009 \\
\hline Hepatitis B surface Ag HBsAg & MNPs & $320 \mathrm{pg} / \mathrm{ml}$ & Wacker et al., 2007 \\
\hline
\end{tabular}


Arugula MA, Zhang Y, Simonian AL (2014) Biosensors as 21st century technology for detecting genetically modified organisms in food and feed. Analytical Chemistry 86: 119-129. doi: 10.1021/ac402898j.

Ayyar BV, Arora S (2013) Antibody-based biosensors for detection of veterinary viral pathogens. Advances in Animal and Veterinary Sciences 1 (4S): 37-44.

Baptista PV (2014) Nanodiagnostics: leaving the research lab to enter the clinics? Diagnosis. 1: 305-309.

Binbin S, Hao Z, Bo L, Wei L, Jixuan W (2016) Label-free insitu real-time DNA hybridization kinetics detection employing microfiber-assisted Mach-Zehnder interferometer. Biosensors and Bioelectronics 81:151-158. doi: 10.1016/j.bios.2016.02.065.

Boltovets PM, Snopok BA, Boyko VR (2004) Detection of plant viruses using a surface plasmon resonance via complexing with specific antibodies. Journal of Virological Methods 121 : 101-106. doi: 10.1016/j.jviromet.2004.06.019.

Bonanni A, Esplandiu MJ, Del Valle M (2009) Impedimetricgenosensors employing $\mathrm{COOH}$-modified carbon nanotube screen-printed electrodes. Biosensors \& Bioelectronics 24: 2885-2891. doi:10.1016/j.bios.2009.02.023.

Carrascosa LG, Huertas CS, Lechuga LM (2016) Prospects of optical biosensors for emerging label-free RNA analysis. TrAC Trends in Analytical Chemistry 80:177-189. doi: 10.1016/j.trac.2016.02.018.

Cascio A, Bosilkovski M, Rodriguez AJM, Pappas G (2011) The socio-ecology of zoonotic infections. Clinical Microbiology and Infection $17: 336-342$.

Cevenini L,Calabretta MM, Tarantino G, MicheliniE, Aldo R (2016) Smartphone-interfaced 3D printed toxicity biosensor integrating bioluminescent "sentinel cells". Sensors and Actuators B: Chemical 225 : 249-257. doi:10.1016/j.snb.2015.11.017.

Chalyan T, Guider R, Pasquardini L, Zanetti M, Falke F, Schreuder E, Heideman RG, Pederzolli C, Pavesi L (2016) Asymmetric Mach-Zehnder Interferometer Based Biosensors for Aflatoxin M1 Detection. Biosensors 6:1. doi: 10.3390/bios6010001.

Chang L, Jinming L , Lunan W (2016) Immuno-PCR: An ultrasensitive immunoassay for biomolecular detection. Analytica Chimica Acta 910:12-24. doi: 10.1016/j.aca.2015.12.039

Cheng CL, Chun YY, Chen PH, Ming-Kung (2013) Analytical Methods Salmonella detection using 16S ribosomal DNA/RNA probe-gold nanoparticles and lateral flow immunoassay. Food Chemistry 141 : 2526-2532. 10.1016/j.foodchem.2013.05.089.

Cheng H, Jixiang L, Yu T, Yanyan C, Gang J (2011) Detection of duck hepatitis virus serotype1 by biosensor based on imaging ellipsometry. Current Applied Physics 11 : 353-357. doi: 10.1016/j.cap.2010.08.004.

Baird CL, Myszka DG (2001) Current and emerging commercial optical biosensors. Journal of Molecular Recognition 14-5: 261-268.

Chia WC, Jiunn DL , Ai LS, Chih KY (2011) Non-labeled virus detection using inverted triangular $\mathrm{Au}$ nano-cavities arrayed as SERS-active substrate. Sensors and Actuators B: Chemical 156 : 471-478. doi: 10.1016/j.snb.2011.04.006.

Ching CL, Sadhasivam S, Savitha S, Lin FH (2016) MWCNTFe3O4-based immuno-PCR for the early screening of nasopharyngeal carcinoma. Materials Science and Engineering: C61:422-428.

Connelly J, Kondapalli S, Skoupi M, Parker JL, Kirby B, Baeumner A (2012) Micro-total analysis system for virus detection: microfluidic pre-concentration coupled to liposome-based detection. Analytical and Bioanalytical Chemistry 402: 315-323. doi: 10.1007/s00216-011-5381-9.

Conroy PJ, Hearty S, Leonard P, O'Kennedy RJ (2009) Antibody production, design and use for biosensor-based applications. Seminars in Cell and Developmental Biology 20: 10-26. doi: 10.1016/j.semcdb.2009.01.010.

Corstjens PL, Tjon Kon Fat EM, de Dood CJ, van der Ploegvan Schip JJ, Franken KL, Chegou NN, Sutherland JS, Howe R, Mihret A, Kassa D, van der Vyver M, Sheehama J, Simukonda F, Mayanja-Kizza H, Ottenhoff TH, Walzl G, Geluk A; AE-TBC consortium. (2016) Multi-center evaluation of a user-friendly lateral flow assay to determine IP-10 and CCL4 levels in blood of TB and non-TB cases in Africa. Clinical Biochemistry 49: 22-31. doi: 10.1016/j.clinbiochem.2015.08.013.

Shi D, Huang J, Chuai Z, Chen D, Zhu X, Wang H, Peng J, Wu H, Huang Q, Fu W (2014) Isothermal and rapid detection of pathogenic microorganisms using a nano-rolling circle amplification-surface plasmon resonance biosensor. Biosensors and Bioelectronics 62: 280-287. doi: 10.1016/j.bios.2014.06.066.

Dahlhausen B (2010) Future Veterinary Diagnostics. Journal of Exotic Pet Medicine 19: 117-132. doi: 10.1053/j.jepm.2010.05.006.

Diming Z, Qingjun L (2016) Biosensors and bioelectronics on smartphone for portable biochemical detection. Biosensors and Bioelectronics 75:273-284. doi: 10.1016/j.bios.2015.08.037. 
Douglas SM, Bachelet I, Church GM (2012) A logic-gated nanorobot for targeted transport of molecular payloads. Science 335:831-834. doi: 10.1126/science.1214081.

Elham N, Amir M, Ayyoob A (2016) Colorimetric DNA detection of transgenic plants using gold nanoparticles functionalized with L-shaped DNA probes. Physica E: Lowdimensional Systems and Nanostructures 15:188-195. doi:10.1016/j.physe.2015.09.018

Feng Y, Yang T, Zhang W, Jiang C, Jiao K (2008) Enhanced sensitivity for deoxyribonucleic acid electrochemical impedance sensor: gold nanoparticle/polyaniline nanotube membranes. Analytica Chimica Acta 616: 144-151. doi: 10.1016/j.aca.2008.04.022.

Rivera-Benitez JF, De la Luz-Armendáriz J, SaavedraMontañez M, Jasso-Escutia MÁ, Sánchez-Betancourt I, PérezTorres A, Reyes-Leyva J, Hernández J, Martínez-Lara A, Ramírez-Mendoza H (2016) Co-Infection of classic swine $\mathrm{H} 1 \mathrm{~N} 1$ influenza virus in pigs persistently infected with porcine rubulavirus. Veterinary Microbiology 184 : 31-39. doi: 10.1016/j.vetmic.2016.01.005.

Gero G, Robert L, Jörg-MH, Fred L (2016) Development of a fast and simple test system for the semiquantitative protein detection in cerebrospinal liquids based on gold nanoparticles. Talanta 146: 49-54. doi: 10.1016/j.talanta.2015.08.016.

Giyoung K, Ji HM, Chang YM, Jongguk L (2015) A microfluidic nano-biosensor for the detection of pathogenic Salmonella. Biosensors and Bioelectronics 67:243-247. doi: 10.1016/j.bios.2014.08.023.

Gogolinska A, Nowak W (2013) Molecular basis of lateral force spectroscopy nano-diagnostics: computational unbinding of autism related chemokine MCP-1 from IgG antibody. Journal of Molecular Modeling 19 : 4773-4780. doi: 10.1007/s00894-013-1972-z.

Guangxin Y, Huisheng Z, Hanyu C, Xianyin P, Dan B (2015) A gold nanoparticle based immunosorbent bio-barcode assay combined with real-time immuno-PCR for the detection of polychlorinated biphenyls. Sensors and Actuators B: Chemical 214:152-158. doi:10.1016/j.snb.2015.02.128.

Gurpreet K, Paliwal A, Tomar M, Gupta V (2016) Detection of Neisseria meningitidis using surface plasmon resonance based DNA biosensor. Biosensors and Bioelectronics 78:106-110. doi: 10.1016/j.bios.2015.11.025.

Ravan H (2016) Isothermal RNA detection through the formation of DNA concatemers containing HRP-mimicking DNAzymes on the surface of gold nanoparticles. Biosensors and Bioelectronics 80: 67-73. doi: 10.1016/j.bios.2016.01.047.

Mukundan H, Anderson AS, Grace WK, Grace KM, Hartman N, Martinez JS, Swanson BI (2009) Waveguide-Based
Biosensors for Pathogen detection. Sensors 9:5783-5809. doi: $10.3390 / \mathrm{s} 90705783$.

Homola J (2003) Present and future of surface plasmon resonance biosensors. Analytical and Bioanalytical Chemistry $377: 528-539$.

Hsieh SC, Chang CC, Lu CC, Wei CF, Lin CS, Lai HC, Lin CW (2012) Rapid identification of Mycobacterium tuberculosis infection by a new array format-based surface plasmon resonance method. Nanoscale Research Letters 7 :180. doi: 10.1186/1556-276X-7-180.

Lin HY, Huang CH, Lu SH, Kuo IT, Chau LK (2014) Direct detection of orchid viruses using nanorod-based fiber optic particle plasmon resonance immunosensor. Biosensors and Bioelectronics 51:371-378. doi: 10.1016/j.bios.2013.08.009.

Wei H, Erkang W (2013) Nanomaterials with enzyme-like characteristics (nanozymes): next-generation artificial enzymes. Chemical Society Reviews 42: 6060-6093. doi: $10.1039 / \mathrm{c} 3 \operatorname{cs} 35486 \mathrm{e}$.

Hwan LJ, Hyuk SS, Jung HK, Hee TK, Kwon KC, Sang JS, Young JC, Jeewon L (2015) Multiplex diagnosis of viral infectious diseases (AIDS, hepatitis C, and hepatitis A) based on point of care lateral flow assay using engineered proteinticles. Biosensors and Bioelectronics 69:213-225. doi: 10.1016/j.bios.2015.02.033.

Jahanshahi P, Zalnezhad E, Sekaran SD, Adikan FR (2014) Rapid immunoglobulin M-based dengue diagnostic test using surface plasmon resonance biosensor. Scientific Reporters 4:3851. doi: $10.1038 /$ srep03851.

Jeremy JR (1997) Optical biosensors. Journal of Molecular Recognition 10-3:109-120. DOI: $10.1002 /(\mathrm{SICI}) 1099-$ 1352(199705/06)10:3<109::AID-JMR361>3.0.CO;2-D.

Ji-Hoon, Dongyoung L, Charleson H, Chuang C, Taeheon K, James JP (2016) A multi-virus detectable microfluidic electrochemical immunosensor for simultaneous detection of $\mathrm{H} 1 \mathrm{~N} 1, \mathrm{H} 5 \mathrm{~N} 1$, and H7N9 virus using $\mathrm{ZnO}$ nano rods for sensitivity enhancement. Sensors and Actuators B: Chemical 228:36-42. doi: 10.1016/j.snb.2015.07.068.

Jiang C, Yang T, Jiao K, Gao H (2008) A DNA electrochemical sensor with poly-L-lysine/single-walled carbon nanotubes films and its application for the highly sensitive EIS detection of PAT gene fragment and PCR amplification of NOS gene. Electrochimica Acta 53: 29172924. doi:10.1016/j.electacta.2007.11.015.

Jiang Q, Song C, Nangreave J, Liu X, Lin L, Qiu D, Wang ZG, Zou G, Liang X, Yan H, Ding B (2012) DNA origami as a carrier for circumvention of drug resistance. Journal of American Chemical Society 134:13396-13403. doi: 10.1021/ja304263n. 
Jiang X, Chen K, Han H (2011) Ultrasensitive electrochemical detection of Bacillus thuringiensis transgenic sequence based on in situ Ag nanoparticles aggregates induced by biotinstreptavidin system. Biosensors and Bioelectronics 28: 464468. doi: 10.1016/j.bios.2011.07.042.

Joshi VG, Kantaraja C, Arvind KS, Aditya PS, Vikas DD, Dimpal T, Ashok KT, Satish K (2013) Rapid label-free visual assay for the detection and quantification of viral RNA using peptide nucleic acid (PNA) and gold nanoparticles (AuNPs). Analytica Chimica Acta 795:1-7. doi: 10.1016/j.aca.2013.06.037.

Juntunen E, Riikka A, Kalliomäki L, Salminen T, Sheikh MT, Tiina M,Tero S, Pettersson K (2016) Effects of blood sample anticoagulants on lateral flow assays using luminescent photon-upconverting and $\mathrm{Eu}$ (III) nanoparticle reporters. Analytical Biochemistry 492:13-20. doi: 10.1016/j.ab.2015.09.009.

Jyoti S, Shivesh S, Seema N (2015) Evaluation of gold nanoparticle based lateral flow assays for diagnosis of enterobacteriaceae members in food and water. Food $\begin{array}{lllll}\text { Chemistry } & 170 \quad \text { : } & 470-483 . & \text { doi: }\end{array}$ 10.1016/j.foodchem.2014.08.092.

Krejcova L, Michalek P, Rodrigo MM, Heger Z, Krizkova S, Vaculovicova M, Hynek D, Adam V, Kizek R (2015) Nanoscale virus biosensors: state of the art. Nanobiosensors in Disease Diagnosis 4:47-66. doi: 10.2147/NDD.S56771.

Kunda JS, Jitendra SS, Nam HK, Joong HL (2016) FeMoO4 based, enzyme-free electrochemical biosensor for ultrasensitive detection of norepinephrine. Biosensors and Bioelectronics 81: 445-453. doi: 10.1016/j.bios.2016.03.029.

Li HB, Wang X (2016) Nonlinear frequency shift behavior of graphene-elastic-piezoelectric laminated films as a nano-mass detector. International Journal of Solids and Structures 84 : 1726. doi: 10.1016/j.ijsolstr.2015.12.011.

Liedberg B, Nylander C, Lunstrom I (1983) Surface plasmon resonance for gas detection and biosensing. Sensors and actuators 4: 299-304. doi:10.1016/0250-6874(83)85036-7.

Liming O, Qingyu L, Canjun W, Huaijie H, Yuling Z, Yongqiang J (2016) Development of a lateral flow immunochromatographic assay for rapid detection of Mycoplasma pneumoniae-specific $\operatorname{IgM}$ in human serum specimens. Journal of Microbiological Methods 124:35-40. doi: 10.1016/j.mimet.2016.03.006.

Longyan C, Hongping W, Yongchao G, Zongqiang C, Zhiping Z, Xian Z (2009) Gold nanoparticle enhanced immuno-PCR for ultrasensitive detection of Hantaan virus nucleocapsid protein. Journal of Immunological Methods 346 : 64-70. doi: 10.1016/j.jim.2009.05.007.
Lucie P, Filip F, Monika B, Petr D (2011) Rapid and sensitive detection of cytokines using functionalized gold nanoparticle-based immuno-PCR, comparison with immunoPCR and ELISA. Journal of Immunological Methods 371: 3847. doi: 10.1016/j.jim.2011.06.012.

Ma Y, Jiao K, Yang T, Sun D (2008) Sensitive PAT gene sequence detection by nano-SiO2/p-aminothiophenol selfassembled films DNA electrochemical biosensor based on impedance measurement. Sensors and Actuators B Chemical 131: 565-571. doi: 10.1016/j.snb.2007.12.046.

MacKenzie D (2015) Renaissance rulers plotted biowar with hats. New Scientist 228:7-57. doi:10.1016/S02624079(15)31691-2.

Mafra I, Ferreira IMPLVO, Oliveira MBPP (2008) Food authentication by PCR-based methods. European Food Research and Technology 227: 649-665.

Manzanares-Palenzuela CL, Martín-Fernández B, SánchezPaniaguaLópez M, andLópez-Ruiz B (2015) Electrochemical genosensors as innovative tools for detection of genetically modified organisms. Trends in Analytical Chemistry 66: 1931. doi: 10.1016/j.trac.2014.10.006.

Marazuela M, Moreno BM (2002) Fiber-optic biosensors - an overview. Analytical and Bioanalytical Chemistry 372 : 664682.

Mascini M, Del Carlo M, Minunni M, Chen B, Compagnone D (2005) Identification of mammalian species using genosensors. Bioelectrochemistry 67: 163-169.

Matthew A (2002) Optical biosensors in drug discovery. Nature Reviews Drug Discovery 1: 515-528.

Navarro Y, Romero B, Bouza E, Domínguez L, Juan L (2016) Detailed chronological analysis of microevolution events in herds infected persistently by Mycobacterium bovis. Veterinary Microbiology 183:97-102. doi: 10.1016/j.vetmic.2015.11.032.

Netrapal S, Vishnubhatla S, Abhishek S, Suman S, Krishna BG,Gopal KK, Promod KM (2016) Serodiagnostic potential of immuno-PCR using a cocktail of mycobacterial antigen 85B, ESAT-6 and cord factor in tuberculosis patients. Journal of Microbiological Methods. 120:56-64. doi: 10.1016/j.mimet.2015.11.016.

Ning G , Wang L, Li TH, Zheng L, Wang F (2009) Reagentless Amperometric Immunosensor Based on Human Immunodeficiency Virus Diagnosis Marker Glycoprotein 160 Antibody Coated Gold-Magnetic Particles Modified Electrode. Chinese Journal of Analytical Chemistry 37 : 1125-1130. doi:10.1016/S1872-2040(08)60121-8.

Ning S, Congliang D, Xiaoli Z, Qi Z, Guanglu G, Yi L, Wenlong Y, Qiang X (2014) Extraction of total nucleic acid 
based on silica-coated magnetic particles for RT-qPCR detection of plant RNA virus/viroid. Journal of Virological Methods 196: 204-211. doi: 10.1016/j.jviromet.2013.11.012.

Oluwasesan A, Tatsuya K, Enoch YP (2016) An ultrasensitive alloyed near-infrared quinternary quantum dot-molecular beacon nanodiagnosticbioprobe for influenza virus RNA. Biosensors and Bioelectronics 80:483-490. doi: 10.1016/j.bios.2016.02.020.

Patel S, Nanda R, Sahoo S, Mohapatra E (2016) Biosensors in health care: the milestones achieved in their development towards lab-on-chip-analysis. Biochemistry Research International Article 3130469, http://dx.doi.org/10.1155/2016/3130469.

Pattnaik P (2005) Surface plasmon resonance. Applied Biochemistry and Biotechnology 126-2: 79-92.

Pedrero M, Campuzano S, Pingarrón JM (2011) Electrochemical genosensors based on PCR strategies for microorganisms detection and quantification. Analytical Methods 3: 780-789. doi: 10.1039/C0AY00755B.

Pohanka M (2013) Cholinesterases in biorecognition and biosensor construction, a review. Analytical Letters 46 : 1849 1868.

Qian S, Guangying Z, Wenchao D (2016) An optical and rapid sandwich immunoassay method for detection of Salmonella pullorum and Salmonella gallinarumbased on immune blue silica nanoparticles and magnetic nanoparticles. Sensors and Actuators B: Chemical 226: 69-75. doi: 10.1016/j.aca.2015.09.041.

Qing L, Yong S, Jack SK, Kyoung WK, Siti R, Mohamed R (2015) Mach-Zehnder interferometer (MZI) point-of-care system for rapid multiplexed detection of microRNAs in human urine specimens. Biosensors and Bioelectronics 71:365-372. doi: 10.1016/j.bios.2015.04.052.

Radhika SK, Justin D, Pratheesh MD, Anoopraj R, Joseph (2008) Biosensor: A novel approach for pathogen detection Review. Vetscan 7:1-102.

Radwan SH, Azzazy HM (2009) Gold nanoparticles for molecular diagnostics. Expert Review of Molecular Diagnostics 9: 511-524. DOI:10.1586/erm.09.33.

Randolph DG, Nancy JM, Dickson K, Saher M, Robert JT, Chad AO (2016) Enhancement of pathogen detection and therapy with laser-activated, functionalized gold nanoparticles. Applications of Nanobiomaterials 6:229-260.

Rathee K, Dhull V, Dhull R, Singh S (2016) Biosensors based on electrochemical lactate detection: A comprehensive review. Biochemistry and Biophysics Reports 5:35-54. doi: 10.1016/j.bbrep.2015.11.010.
Richards SL, Cawley AT, Cavicchioli R, Suann CJ, Pickford R, Raftery ML (2016) Aptamer based peptide enrichment for quantitative analysis of gonadotropin-releasing hormone by LC-MS/MS. Talanta 150:671-680. doi: 10.1016/j.talanta.2016.01.006.

Rithesh DR, Prasanth S, Vineeshkumar TV, Sudarsanakumar C (2016) Surface Plasmon Resonance based fiber optic sensor for mercury detection using gold nanoparticles PVA hybrid. Optics Communications 367:102-107. doi:10.1016/j.optcom.2016.01.027.

Roda A , Mirasoli M, Michelini E, Massimo DF, Zangheri M, Cevenini L, Barbara, Patrizia S (2016) Progress in chemical luminescence-based biosensors: A critical review. Biosensors and Bioelectronics. 76:164-179. doi: 10.1016/j.bios.2015.06.017.

Ruihua T,Hui Y, Jane RC, Yan G, Jie H, Shangsheng F, Belinda PM, Qibing M, Feng X (2016) Improved sensitivity of lateral flow assay using paper-based sample concentration technique. Talanta 152:269-276. doi: 10.1016/j.talanta.2016.02.017.

Ruiyan S, Huisheng Z (2015) An ultrasensitive gold nanoparticles improved real-time immuno-PCR assay for detecting diethyl phthalate in foodstuff samples. Analytical Biochemistry 480: 49-57. doi: 10.1016/j.ab.2015.04.010.

Schmitt K, Schirmer B, Hoffmann C, Brandenburg A, Meyrueis P (2007) Interferometric biosensor based on planar optical waveguide sensor chips for label-free detection of surface bound bioreactions. Biosens Bioelectron 22 :25912597.

Schneider BH, Dickinson EL, Vach MD, Hoijer JV, Howard LV (2000) Highly Sensitive ChipImmunoassays in Human Serum. Biosensor Bioelectron 15: 13-22. doi:10.1016/S09565663(00)00056-7.

Seeman, Nadrian C (2004) Nanotechnology and the double helix. Scientific American 290 : 64-75.

Seon AJ, Shishir P, Ernesto E, Richard MJ, Kuhn, Lia A (2016) Impedimetric Dengue Biosensor based on Functionalized Graphene Oxide Wrapped Silica Particles. Electrochimica Acta 194:422-430. doi:10.1016/j.electacta.2016.02.116.

Sherif MS, Dirk B, Hassan ME (2010) Direct detection of unamplified hepatitis $\mathrm{C}$ virus RNA using unmodified gold nanoparticles.Azzazy. Clinical Biochemistry 43:1163-1168. doi: 10.1016/j.clinbiochem.2010.07.001.

Song X, Shi S, Swanson BI (2000) Flow Cytometry-based Biosensor for Detection of Multivalent Proteins. Analytical Biochemistry 284: 35-41. doi:10.1006/abio.2000.4664. 
Stegurova L, Eduarda D, Ales B, Pavel D, Daniela R, Petr D (2014) Gold nanoparticle-based immuno-PCR for detection of tau protein in cerebrospinal fluid. Journal of Immunological Methods 406:137-142. doi: 10.1016/j.jim.2014.03.007.

Stephen BJ, Singh SV, Datta M, Jain N, Jayaraman S, Chaubey KK, Gupta S, Singh M, Aseri GK, Khare N, Yadav P, Dhama K, Sohal JS (2015) Nanotechnological Approaches for the Detection of Mycobacteria with Special References to Mycobacterium avium Subspecies Paratuberculosis (MAP). Asian Journal of Animal and Veterinary Advances 10: 518526. doi:10.3923/ajava.2015.518.526.

Stringer RC, Schommer S, Hoehn D, Grant SA (2008) Development of an optical biosensor using gold nanoparticles and quantum dots for the detection of porcine reproductive and respiratory syndrome virus. Sensors Actuators B: Chemical 134: 427-431. doi:10.1016/j.snb.2008.05.018.

Syed MA (2014) Advances in nanodiagnostic techniques for microbial agents. Biosensors and Bioelectronics 51:391-400. doi: 10.1016/j.bios.2013.08.010.

Tereshchenko A, Bechelany M, Roman V, Volodymyr K, Valentyn, Nikolay S, Yakimova R (2016) Optical biosensors based on $\mathrm{ZnO}$ nanostructures: advantages and perspectives. A review. Sensors and Actuators B: Chemical 229: 664-671. doi:10.1016/j.snb.2016.01.099.

Thiagarajan V, Madhurantakam S, Swaminathan S, Rayappan JBS, Krishnan UM (2016) Nano interfaced biosensor for detection of choline in triple negative breast cancer cells. Journal of Colloid and Interface Science 462:334-340. doi: 10.1016/j.jcis.2015.10.014.

Tianshu W, Jiyang L, Xiaoxiao G, Dan L, Jin W, Erkang W (2015) Label-free electrochemical aptasensor constructed by layer-by-layer technology for sensitive and selective detection of cancer cells. Analytica Chimica Acta 882:32-37. doi: 10.1016/j.aca.2015.05.008.

Tørring T, Gothelf KV (2013). DNA nanotechnology: a curiosity or a promising technology? F1000Prime Rep.5:14. doi: 10.12703/P5-14.

Tran QH, Nguyen THH, Mai AT, Nguyen TT, Vu QK, Phan TN (2012) Development of electrochemical immunosensors based on different serum antibody immobilization methods for detection of Japanese encephalitis virus. Advances in Natural Sciences: Nanoscience and Nanotechnology 3: 015012. doi: 10.1088/2043-6262/3/1/015012.

Tseng TY, Wang CH, Chang CP, Lee GB (2016) Microfluidic System for Rapid Detection of Influenza H1N1 Virus Using a Sandwich-based aptamer assay. Biosensors and Bioelectronics. doi:10.1016/j.bios.2016.03.073.
Wacker R, Buelent C, Petra A, Schueler D, Claus L, Christof MN (2007) Magneto Immuno-PCR: A novel immunoassay based on biogenic magnetosome nanoparticles. Biochemical and Biophysical Research Communications 357 : 391-396.

Wang Y, Chen X, Jiong L, Hsing MI, Mansun C (2010) A CMOS active pixel sensor based DNA micro-array with nanometallic particles detection protocol. Solid-State Electronics 49 : 1933-1936. doi: 10.1016/j.sse.2005.09.015.

Wanzhe Y, Yanan L, Peng L, Qinye S, Limin L, Jiguo S (2015) Development of a nanoparticle-assisted PCR assay for detection of porcine epidemic diarrhea virus. Journal of Virological Methods 220:18-20. doi: 10.1016/j.jviromet.2015.04.008.

Weber MN, Bauermann FV, Bayles DO, Canal CW, Neill JD, Ridpath JF (2016) Comparison of 'HoBi'-like viral populations among persistent infected calves generated under experimental conditions and to inoculum virus. Virology 492:225-231. doi: 10.1016/j.virol.2016.03.001.

Wenjie Y, Tingting L, Jicheng B, Wen K (2016) Label-free fiber optic biosensor based on thin-core modal interferometer. Sensors and Actuators B: Chemical228:322-329. doi:10.1016/j.snb.2016.01.029.

Wenjun Z, Yunqing D, Wang ML (2015) Noninvasive glucose monitoring using saliva nano-biosensor. Sensing and BioSensing Research 4:23-29. doi:10.1016/j.sbsr.2015.02.002.

Xiaocui F, Yang T, Luoyang W, Jibing Y, Xiuli W, Yinjian Z, Wang C, Liang W (2016) Nano-cage-mediated refolding of insulin by PEG-PE micelle. Biomaterials 77:139-148. doi: 10.1016/j.biomaterials.2015.11.007.

Xiaohui L, Mingshun J , Qingmei S, Shuyang L, Xiangyi G. (2016) Optical fiber Fabry-Perot interferometer for microorganism growth detection. Optical Fiber Technology 30:32-37. doi:10.1016/j.yofte.2016.01.014.

Xiaoxia M, Siyu L, Chao Y, Fengzhen L, Keming W, Guifang C (2016) Colorimetric detection of hepatitis B virus (HBV) DNA based on DNA-templated copper nanoclusters. Analytica Chimica Acta 909:101-108. doi: 10.1016/j.aca.2016.01.009.

Xie YJ, Yang Y, Kong K, Yang SH, Yang MH (2015) Application of Nanoparticle Probe-based Lateral Flow Immunochromatographic Assay in Mycotoxins Detection. Chinese Journal of Analytical Chemistry 43 : 618-628. doi:10.1016/S1872-2040(15)60821-0.

Xiuli F, Ziyi C, Jimin Y, Priscilla C, Lingxin C, Jaebum C (2016) A SERS-based lateral flow assay biosensor for highly sensitive detection of HIV-1 DNA. Biosensors and Bioelectronics 78:530-537. doi: 10.1016/j.bios.2015.11.099. 
Xudong F, Ian M, White, Siyka ,Shopova, Hongying Z, Jonathan D (2008) Sensitive optical biosensors for unlabeled targets: A review. Analytica chimica acta 620 8-26. doi:10.1016/j.aca.2008.05.022.

Yadav BS, Mayank B, Barkha R, Ajay K, Meeta S, Bhaskar S (2015) Viral diagnosis in Indian livestock using customized microarray chips. Bioinformation 11 : 489-492. doi: 10.6026/97320630011489.

Yadav TK, Narayanaswamy R, Abu Bakar MH, Kamil YM, Mahdi MA (2014) Single mode tapered fiber-optic interferometer based refractive index sensor and its application to protein sensing. Opt Express 22 : 22802-22807. doi: 10.1364/OE.22.022802.

Yanase Y, Hiragun T, Ishii K, Kawaguchi T, Yanase T, Kawai M, Sakamoto K, Hide M (2014) Surface plasmon resonance for cell-based clinical diagnosis. Sensors (Basel) $14:$ 49484959. doi:10.3390/s140304948.

Yang J, Jiao K, Yang T (2007a) A DNA electrochemical sensor prepared by electrodepositing zirconia on composite films of single-walled carbon nanotubes and poly(2,6pyridinedicarboxylic acid), and its application to detection of the PAT gene fragment. Analytical and Bioanalytical Chemistry 389: 913-921.

Yang J, Wang X, Shi H (2012) An electrochemical DNA biosensor for highly sensitive detection of phosphinothricinacetyltransferase gene sequence based on polyaniline-(mesoporousnanozirconia)/poly-tyrosine film. Sensors and Actuators B: Chemical 162: 178-183. doi:10.1016/j.snb.2011.12.064.

Yang J, Yang T, Feng Y, Jiao K (2007b) A DNA electrochemical sensor based on nanogold-modified poly-2,6pyridinedicarboxylic acid film and detection of PAT gene fragment. Analytical Biochemistry 365: 24-30. doi:10.1016/j.ab.2006.12.039.

Yang T, Zhang W, Du M, Jiao K (2008) A PDDA/poly (2, 6pyridinedicarboxylic acid)-CNTs composite film DNA electrochemical sensor and its application for the detection of specific sequences related to PAT gene and NOS gene. Talanta 75: 987-994.

Yang T, Zhou N, Zhang Y, Zhang W, Jiao K, Li G (2009) Synergistically improved sensitivity for the detection of specific DNA sequences using polyanilinenanofibers and multi-walled carbon nanotubes composites. Biosensors and Bioelectronics 24: 2165-2170. doi: 10.1016/j.bios.2008.11.011.

Yanlin Z, Ian DM, Robert WC, Spas DK (2016) Colorimetric detection based on localised surface plasmon resonance of gold nanoparticles: Merits, inherent shortcomings and future prospects. Talanta

10.1016/j.talanta.2016.02.015.

Yanxia L, Mei H, Bin Q, Zhenyu L, Yiting C, Zongwei C, Guonan C (2014) Highly sensitive fluorescent immunosensor for detection of influenza virus based on $\mathrm{Ag}$ autocatalysis. Biosensors and Bioelectronics 54:358-364. doi: 10.1016/j.bios.2013.10.045.

Yaru Z, Bin Z, Xiaoli Y, Yuqi Y, Langhuan H, Zhenyou J, Shaozao T, Xiang C (2016) Electrochemical immunosensor for interferon- $\gamma$ based on disposable ITO detector and HRPantibody-conjugated nano gold as signal tag. Materials Science and Engineering: C 59: 577-584. doi: 10.1016/j.msec.2015.10.066.

Yasuo S, Mami N, Risa Y, Mami O, Kazue A, Zhang X (2015) Highly sensitive detection of influenza virus in saliva by real-time PCR method using sugar chain-immobilized gold nanoparticles; application to clinical studies. Biotechnology Reports 7:64-71. doi:10.1016/j.btre.2015.05.004

Yen TT, Cheng C, Chang, Yi LL, Shie LH, Gou JW (2016) Development of double-generation gold nanoparticle chipbased dengue virus detection system combining fluorescence turn-on probes. Biosensors and Bioelectronics 77: 90-98. doi: 10.1016/j.bios.2015.09.007.

Yortyot SN, Wansadaj J, Siriporn S, Rungkarn S, Wansika K (2013) Visual detection of white spot syndrome virus using DNA-functionalized gold nanoparticles as probes combined with loop-mediated isothermal amplification. Molecular and Cellular Probes 27: 71-79. doi: 10.1016/j.mcp.2012.11.005.

Zhang W, Yang T, Jiang C, Jiao K (2008) DNA hybridization and phosphinothricin acetyl transferase gene sequence detection based on zirconia/nanogold film modified electrode. Applied Surface Science 254: 4750-4756. doi:10.1016/j.apsusc.2008.01.102.

Zhao Y-X, Shaw A, Zeng X, Benson E, Nyström AM, Högberg B (2012) DNA origami delivery system for cancer therapy with tunable release properties. ACS Nano. 6:86848691. doi: $10.1021 / \mathrm{nn} 3022662$.

Zhou N, Yang T, Jiang C, Du M, Jiao K (2009) Highly sensitive electrochemical impedance spectroscopic detection of DNA hybridization based on Au-nano-CNT/PAN(nano) films. Talanta. 77: 1021-1026. doi: 10.1016/j.talanta.2008.07.058. 